\author{
Grzegorz Lenda ${ }^{1}$ \\ ORCID: 0000-0001-8876-1055 \\ Dominika Spytkowska \\ ORCID: 0000-0003-0198-2790
}

\title{
EFFECTIVENESS ANALYSIS OF SPLINE SURFACES CREATING METHODS FOR SHELL STRUCTURES MODELLING
}

\author{
${ }^{1}$ AGH University of Science and Technology, Faculty of Mining Surveying and Environmental Engineering, Kraków, Poland \\ grzenda@agh.edu.pl \\ ${ }^{2}$ AGH University of Science and Technology, Faculty of Mining Surveying and Environmental Engineering, Kraków, Poland \\ spytkowska.dominika@gmail.com
}

Keywords: modelling, spline functions, NURBS, shell structures, laser scanning

\begin{abstract}
The shape of the surface of shell structures, measured by laser scanning, can be modelled using approximating spline functions. Since the 1990s, several modelling techniques have been developed: based on points, meshes, areas outlined on meshes, regions grouping areas with a similar structure. The most effective of them have been used in modern software, but their implementations differ significantly. The most important differences concern the accuracy of modelling, especially places with rapid shape changes, including edges. The differences also affect the mathematical complexity of the created model (the number of unknowns) and the time of its development. These factors contribute to the effectiveness of modelling. Some methods work fully automatically, others allow manual selection of certain parameters, there are also methods that require full manual control. Their selection and application is greatly affected by the user's intuition and knowledge in the field of creating such surfaces. This study tested the influence of the above factors on the modelling efficiency. A total of six methods of creating spline surfaces were analysed in three software packages of different classes: Geomagic Design X, Solidworks and RhinoResurf. The analyses were carried out on a shell structure of complex shape, consisting of seven patches separated by edges. The created models were assessed in terms of their accuracy of fitting into the point cloud. Additionally, the complexity of the model expressed in the number of control points and the time of its development were determined. The results confirmed the validity of the four methods in terms of model fitting accuracy. The best results were achieved using the semi-automatic method in the most advanced software package and the manual method in the simplest package. This has confirmed the great importance of user experience in terms of theoretical properties of spline functions. However, complexity and development time did not show a direct relationship with the accuracy of the models created.
\end{abstract}

\section{ANALIZA EFEKTYWNOŚCI METOD TWORZENIA POWIERZCHNI SKLEJANYCH DLA MODELOWANIA OBIEKTÓW POWLOKOWYCH}

Słowa kluczowe: modelowanie, funkcje sklejane, NURBS, powłoki, skaning laserowy

\section{Abstrakt}

Modelowanie kształtu powierzchni obiektów powłokowych, pomierzonych za pomocą skaningu laserowego, można przeprowadzić za pomocą aproksymacyjnych funkcji sklejanych. Funkcje te dobrze przybliżają kształty o ciągłej krzywiźnie, jakimi są powłoki, jednocześnie wykazując spadki dokładności w miejscach zerwania tej ciągłości. Od lat 90. XX wieku rozwinęło się 
kilka technik modelowania za ich pomocą, m.in.: wykorzystujących same punkty, siatki mesh, obszary obrysowane na siatkach mesh, regiony grupujące obszary o podobnej strukturze. Najbardziej skuteczne z nich zostały zastosowane we współczesnym oprogramowaniu, ale ich implementacje znacząco się pomiędzy sobą różnią. Najważniejsze różnice dotyczą dokładności modelowania, szczególnie miejsc o szybkich zmianach kształtu, włączając w nie krawędzie. Różnice dotyczą też złożoności matematycznej utworzonego modelu (liczby niewiadomych) oraz czasu jego opracowania. Czynniki te składają się na efektywność modelowania. Część metod działa w pełni automatycznie, inne pozwalają na ręczny dobór pewnych parametrów, są też metody wymagające pełnego sterowania ręcznego. W ich wyborze i stosowaniu duże znaczenie ma intuicja i wiedza użytkownika w zakresie tworzenia tego typu powierzchni. W opracowaniu przetestowano wpływ powyższych czynników na efektywność modelowania. Badaniom poddano łącznie sześć metod tworzenia powierzchni sklejanych $\mathrm{w}$ trzech pakietach oprogramowania różnej klasy: Geomagic Design X, Solidworks i RhinoResurf. Analizy przeprowadzono na obiekcie powłokowym o złożonym kształcie, składającym się z siedmiu płatów rozdzielonych krawędziami. Został on pomierzony metodą skaningu laserowego, a scalona chmura punktów stanowiła podstawę do modelowania za pomocą funkcji sklejanych. Utworzone modele oceniono pod względem dokładności wpasowania w chmurę punktów za pomocą wykresów odchyłek punktów od powierzchni, odchyłek średnich oraz maksymalnych. Dodatkowo określono złożoność modelu wyrażoną liczbą punktów kontrolnych oraz czas jego opracowania. Wyniki pozwoliły na potwierdzenie skuteczności czterech metod w zakresie dokładności wpasowania modeli. Najlepsze efekty osiągnięto stosując metodę półautomatycznq̨ w najbardziej zaawansowanym pakiecie oprogramowania oraz metodę ręcznq w najprostszym z pakietów. Potwierdza to duże znaczenie doświadczenia użytkownika w zakresie teoretycznych własności funkcji sklejanych. Złożoność i czas opracowania nie wykazywały natomiast bezpośredniego związku z dokładnością tworzonych modeli.

\section{INTRODUCTION}

Spline surfaces are one of the basic tools for modelling non-linear technical structures, including shell structures. Compared to modelling with quadrics (second-order surfaces) (Ahn 2004, Audin 2003), they have a number of advantages, the most important of which include: precise modelling of structures of any shape, no influence of local deformations on the shape of the entire model and the use of the same mathematical notation for different types of surfaces. However, these surfaces also have disadvantages related to the accuracy of modelling point clouds with rarefied and uneven structure and those containing edges. The disadvantages also include the labour intensity and the number of unknowns that are necessary to be determined when creating models. Spline surfaces are determined using the lofting technique (1) spanning the surface patches on the curves created on the points (Farin 2002, Kiciak 2019, Piegl and Tiller 2012).

$$
\begin{gathered}
S_{i, j}(t, u)=\sum_{i=0}^{m-4} \sum_{j=0}^{n-4} d_{i, j} \cdot N_{i}^{3}(t) \cdot N_{j}^{3}(u) \\
t_{i}=\left\{t_{0}, . ., t_{m}\right\} \\
u_{i}=\left\{u_{0}, . ., u_{n}\right\}
\end{gathered}
$$

where: $S$ - spline surface, $d$ - control points, $N$ - base polynomials, $t, u$ - knots in number $m$ and $n$
It is a general method of constructing interpolation surfaces (Piegl and Tiller 2012) passing strictly through the measured points. In the case of modelling data from laser scanning, such a procedure is ineffective due to the number of points and measurement noise. Then, approximating loft surfaces are used (Kiciak 2019, Koch 2009, Piegl and Tiller 2012), which approximate the set of points with a certain accuracy.

$$
\begin{gathered}
\sum_{k=0}^{r}\left[p_{j}-\sum_{i=0}^{m-4} \sum_{j=0}^{n-4} d_{i, j} \cdot N_{i}^{3}(t) \cdot N_{j}^{3}(u)\right]^{2} \rightarrow \min \\
t_{i}=\left\{t_{0}, . ., t_{m}\right\} \\
u_{i}=\left\{u_{0}, . ., u_{n}\right\}
\end{gathered}
$$

where: $p_{j}$ - points

Each term of the function is based on any number of measured points, provided that it approximates them with sufficient accuracy. Determining the terms for which the accuracy requirement will be met, while aiming to minimise the number of these terms, is the basic problem when creating approximating functions (2). In practice, the final accuracy of the model fitting is verified only after it has been created and may differ significantly in places where the curvature of the structure changes quickly and slowly. Research on the optimisation of approximation algorithms has been ongoing since the 1990s. It has paid off with a full spectrum 
of methods, from the simplest, using the least squares method directly for the point cloud, to the use of neural networks to define regions in which surface patches are formed (Anderson and Crawford-Hines 2000, El-Midany et al. 2011).

Several modelling techniques can be distinguished that use approximating loft surfaces used in modern software. The simplest one is to create a surface directly based on the measured points (Fig. 1a) (Kiciak 2019, Brujic et al. 2011, Leal Narvaez et al. 2011). In this case, the loft surface is created based on a rough evaluation of the geometry of the point cloud, e.g. consisting in determining the regression plane, then used to determine the direction of curves creation and surface spanning. This type of modelling is only effective for structures of uncomplicated shape. The approximation of more complex structures requires pre-processing of the point cloud, allowing to assess local shape changes. For this purpose, triangle meshes are used (Krishnamurthy and Levoy 1996, Wang et al. 2011, Zhang et al. 2002) that are built on the cloud (Fig. 1b). They allow for a more optimal selection of the direction of curve creation and the spanning of the patches, and above all, they enable the selection of appropriate parametrisation, determining the local shape of the spline function (Bhatla 2003, Lim 2002, Shamsuddin and Ahmed 2004). However, the modelling of the most complex shapes requires one more step. Both the directions of creating curves and loft surfaces as well as parametrisation that are optimal in one part of the structure, may be inappropriate in another part of it which differs significantly in shape. In this case, areas are outlined on the triangle mesh, inside which separate gridded loft surfaces are created, each of which may have its own orientation and parametrisation (Fig. 1c) (Eck and Hoppe 1996, Lin et al. 2007, Teutsch et al. 2005, Zhang et al. 2011). It is currently the basic method of modelling with the use of spline surfaces.

There may be cases where a structure has edges that are not precisely modelled by a continuous curvature spline. Then, it is possible to use additional grouping of the loft surfaces into regions with a similar structure (Fig. 2). As the selection of regions can be automatic, in practice it concerns not only edges, but some edges may also be omitted.

The presented methods of creating spline surfaces (NURBS) are used in software that enables modelling

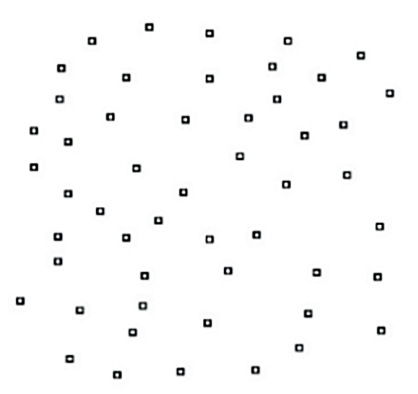

a)

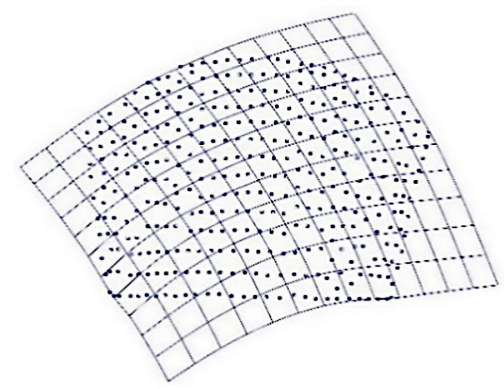

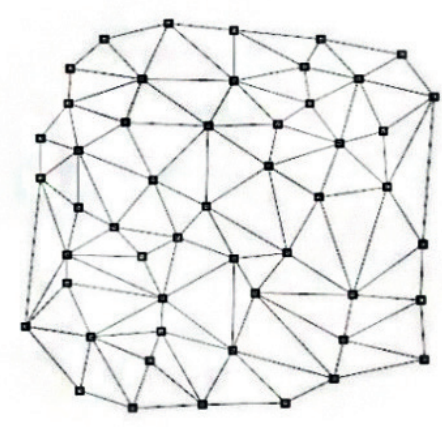

b)

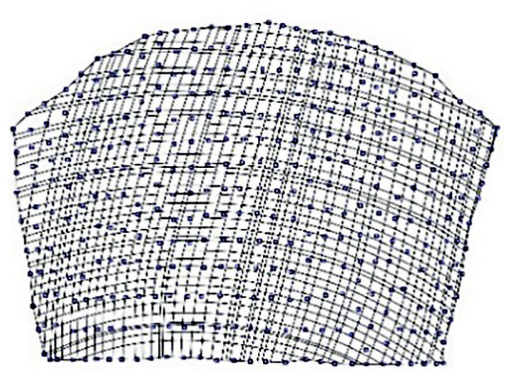

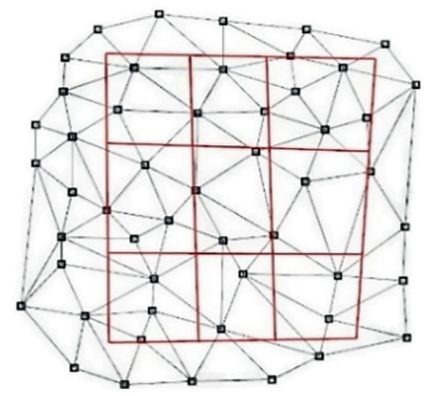

c)

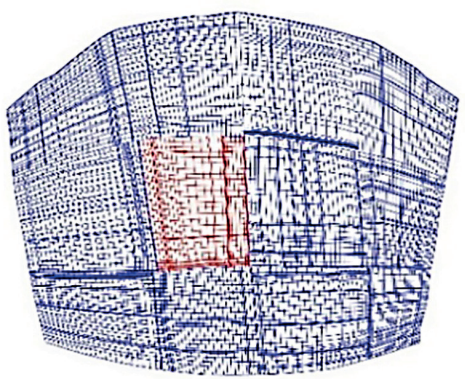

Fig. 1. Methods for creating approximating spline surfaces: a) based on points, b) based on mesh, c) based on gridded areas outlined on mesh

Rys. 1. Metody tworzenia aproksymacyjnych powierzchni sklejanych: a) na podstawie punktów, b) na podstawie mesh, c) na podstawie obszarów obrysowanych na mesh 


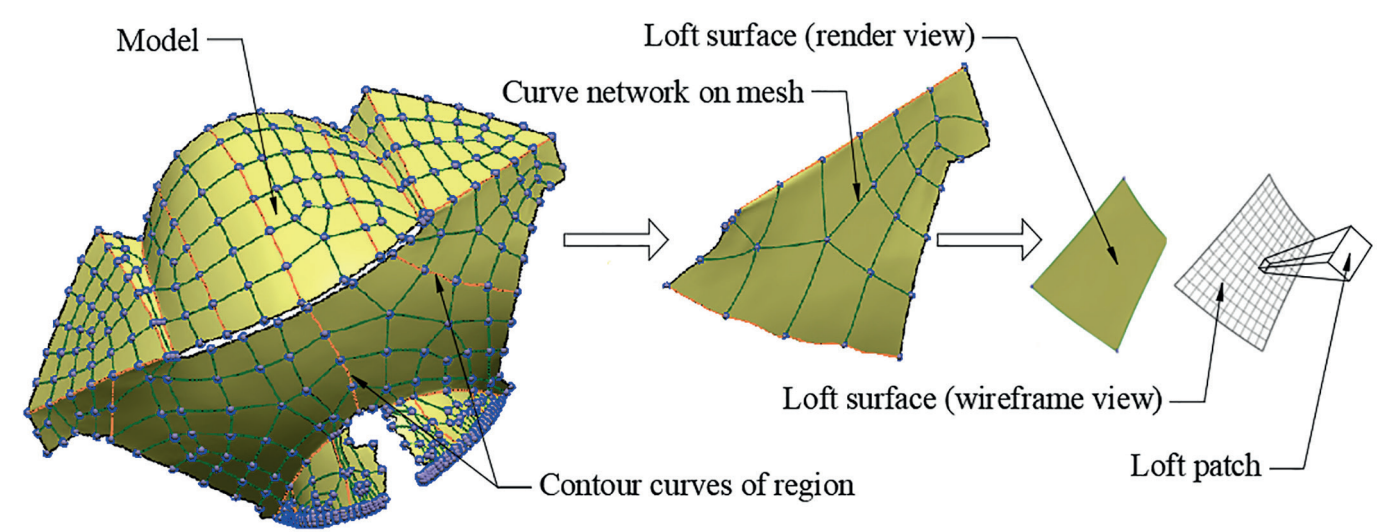

Fig. 2. Spline model components

Rys. 2. Części składowe modelu sklejanego

for the purposes of reverse engineering, including Geomagic Design X, Solidworks, Polyworks, 3D Reshaper, Catia, Rhino Resurf. Despite the similar idea of creating surfaces, the built-in algorithms differ significantly, and each package allows to calculate surfaces in several ways. Unfortunately, the details of the algorithms are a trade secret of the producers and are not shared. The key differences concern the way in which software divides the point cloud into areas into which loft surfaces are fitted and how these surfaces are oriented and parametrised. As a result, there may be differences in the accuracy of modelling the entire surface or its fragments. This applies especially to structures with variable and irregular shape, in particular those with edges.

Significant differences also concern the complexity of the model, expressed in the number of control points. These points are unknowns determined in the process of surface approximation. The number of control points determines the time of calculations related to the determination and subsequent processing of the model, it affects the accuracy of the model and determines the size of the resulting data necessary to remember. It is optimal to achieve the highest possible modelling accuracy with as few control points as possible.

The third factor that differentiates how software works is the time needed to create the model. It includes both the time of calculations performed by the computer and the user's working time.

The aim of this study was to conduct comparative tests of selected modelling packages with the use of spline surfaces for a shell structure of complex shape. The research concerned the most important factor from the modelling point of view, which is the accuracy of fitting the surface to the point cloud. Other factors, i.e. the resulting complexity of the model and the modelling time, were also taken into account. Effective modelling is about finding a compromise between all these factors, and this research was intended to provide an overview of the current capabilities of modeling methods. Depending on the surface generation method used and the assumed modeling objective, this compromise will be subject to change.

\section{RESEARCH PROCEDURE}

Three modelling software were selected for the research: Geomagic Design X, which is the industry standard with the greatest potential, Solidworks with the ScanTo3D plug-in, representing mid-range tools, and RhinoResurf, being an overlay for Rhinoceros, which is one of the cheaper alternatives. The basic assessment criterion was the accuracy of fitting the patch to the point cloud. It was assessed using graphs of deviations of points from the surface. The graphs indicate the values and locations of deviations that belong to the defined accuracy intervals. Five deviation intervals were established, with the first four increasing in $5 \mathrm{~mm}$ increments and the last containing deviations exceeding $20 \mathrm{~mm}$. Tables containing the percentages of individual deviation ranges as well as their average and maximum values were also compared. These data were supplemented with additional factors affecting the modelling efficiency, i.e. the number of model control points and the modelling time.

The tests were carried out on a shell model consisting of seven patches of different geometry separated by 

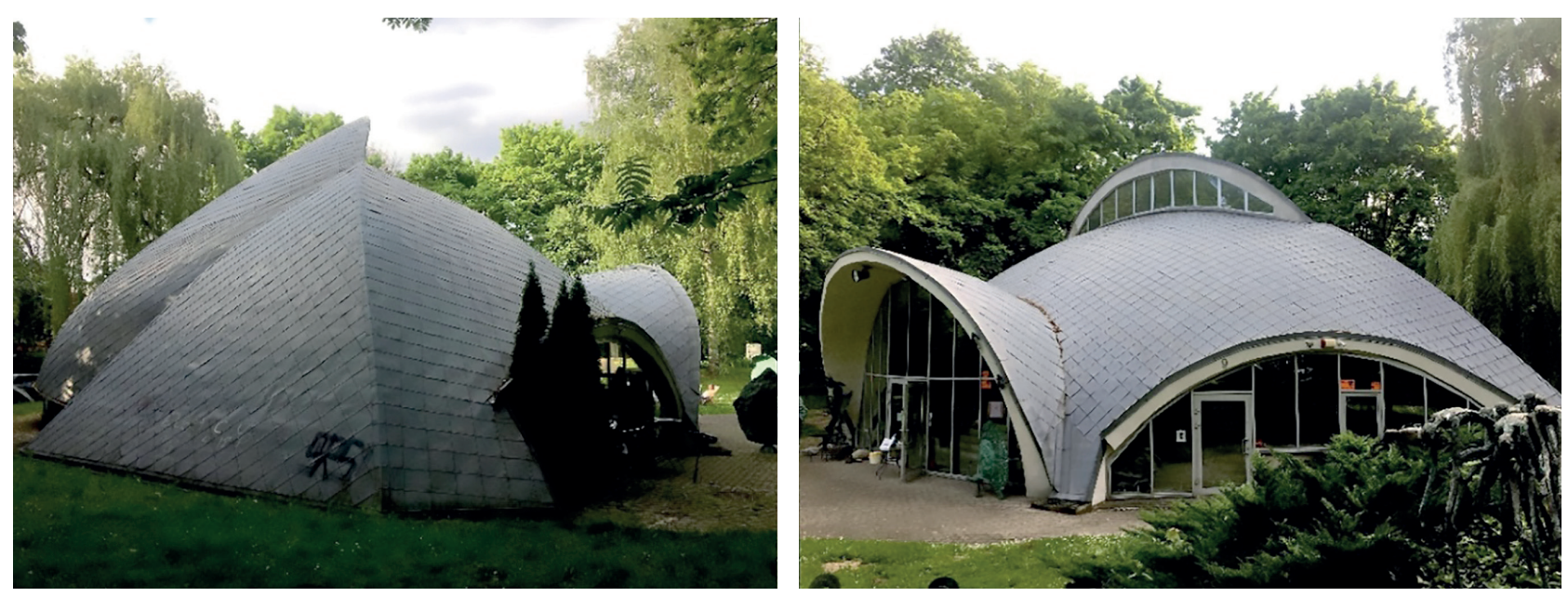

Fig. 3. Shell structure under analysis (B. Chromy's Gallery in Kraków)

Rys. 3. Obiekt powłokowy poddany analizom (Galeria B. Chromego w Krakowie)

edges (B. Chromy's Gallery in Kraków - Fig. 3), which was an additional difficulty in modelling with the use of spline functions.

The structure was measured by laser scanning using the Leica Scanstation $\mathrm{C} 10$ with a point positioning accuracy of $6 \mathrm{~mm}$ and a precision of $2 \mathrm{~mm}$. The measurement was carried out from 10 positions in order to ensure high detail of all elements of the structure. Due to the structure of its surface in the form of metal plates with clear edges and good mutual coverage of adjacent clouds, it was possible to merge adjacent scanner stations with the cloud to cloud method. The errors of merging adjacent point clouds in Leica Cyclone software were 3-6 $\mathrm{mm}$, and the average transformation error for the entire model was $5 \mathrm{~mm}$. The average scanning resolution was $8 \mathrm{~mm}$.

Many of the tiles comprising the surface of the object had local undulations and edge detachments (Fig. 4) that interfered with the resulting model. Their values were estimated to average $10 \mathrm{~mm}$.

The merged and noise-free cloud of points representing the shell is illustrated in Figure 5. It has a gap in the front patch due to the lack of an aiming direction on its upper part.

The data prepared in this way was used to create spline models in three software. In each software, meshes were constructed and spline surfaces were created based on them. The highest fit tolerance was selected

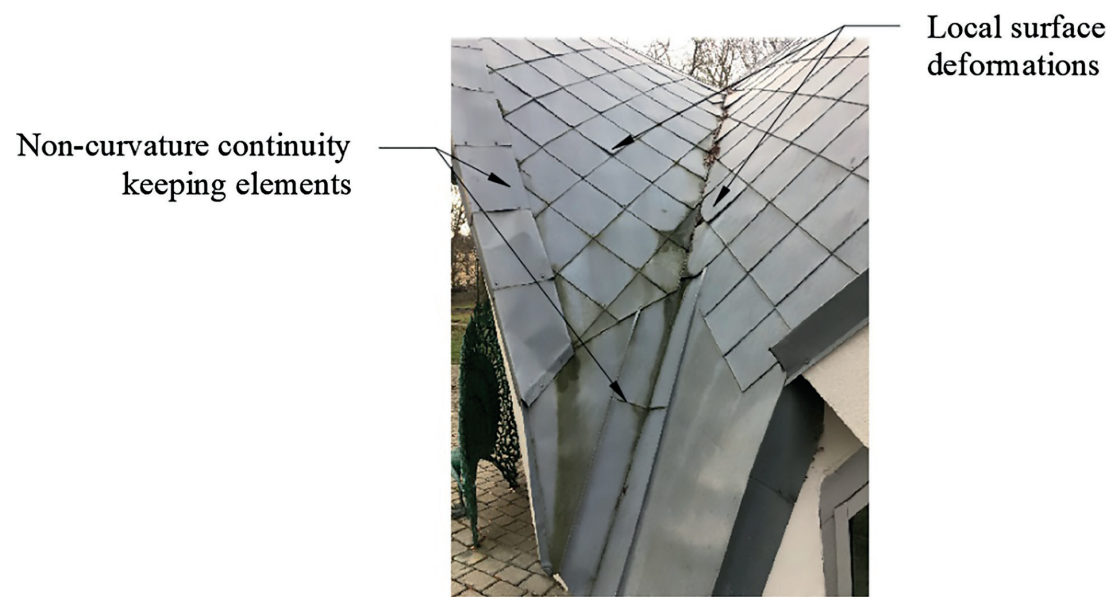

Fig. 4. Local surface deformations and elements not keeping curvature continuity Rys. 4. Lokalne deformacje powierzchni oraz elementy niezachowujące ciągłości krzywizny 


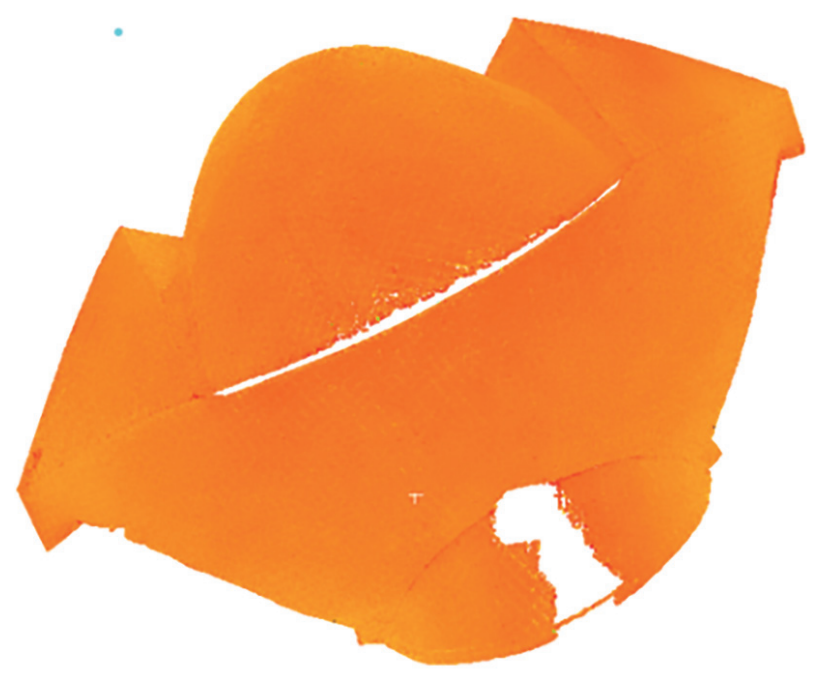

Fig. 5. Point cloud subjected to modelling

Rys. 5. Chmura punktów poddana modelowaniu

for each model. The number of loft surfaces was determined automatically by the software, and if it was impossible, it was determined manually.

In the Geomagic Design $X$ software, the following models were created: automatic mechanical, and semi-automatic. The mechanical model is recommended for creating a surface of technical objects having an ordered structure that may contain edges. The semi-automatic model allows for manual drawing of lines delimiting regions with a similar structure, which was important in the case of a surface consisting of seven patches separated by edges. Graphs of deviations of the point cloud from fitted surfaces are illustrated in Figure 6.

The following models were created in Solidworks software: automatic and guided. The automatic model is similar in operation to the semi-automatic model from the Geomagic software, i.e. it allows for manual correction of lines separating regions with a similar structure. The guided model, on the other hand, allows for the separation of areas that form independent surfaces, not merged with each other with the curvature continuity. These were seven patches of the structure separated by edges. The disadvantage of this model, however, is the limited number of surface guided segments, which may affect the modelling accuracy for patches with a more diversified structure. The maximum number of guided segments available in the program was determined for each patch. The results of fitting the surface to the point cloud in Solidworks are illustrated in Figure 7.
In RhinoResurf, the method of automatic outlining loft areas on a mesh is unreliable, because it creates many unclosed areas where surface patches do not form, and drawing the boundaries manually is very time-consuming. Therefore, two simpler mesh-based models were created in the program: single-surface and multi-surface. The single-surface model created a single loft surface for the entire point cloud, in no way taking into account the edges of the structure. For the multi-surface model, the point cloud was divided into seven parts, corresponding to the structure's patches separated by edges. Then, a mesh was created for each cloud, and one loft surface for it. In the end, the entire model was merged, maintaining only the continuity of the function along the edges. The fit results in RhinoResurf are illustrated in Figure 8.

\section{ANALYSIS OF RESULTS}

In order to compare the efficiency of modelling, taking into account the accuracy of fitting the model to the point cloud, the complexity of the model and the development time, additional tabular data was compiled. Table 1 contains the percentages of individual groups of deviations illustrated in Figures 6-8. Table 2 summarises the mean and maximum deviation values for each model, the number of control points informing about the complexity of the model, and the time needed to create the model.

The most important analysed parameter was the accuracy of the model fit. The values of mean deviations (Tab. 2) demonstrate that the most accurate fit was obtained in the Geomagic software for the semi-automatic model $(1.2 \mathrm{~mm})$. It was possible to create accurate models with an average deviation of fit of 1.6-1.7 mm in each of the software: Geomagic mechanical model, Solidworks automatic model and RhinoResurf multi-surface model. The worse fit was obtained for the single-surface RhinoResurf model $(2.8 \mathrm{~mm})$, and the worst for the Solidworks guided model (4.8 mm). Maximum deviations (Tab. 2) are useful for the assessment of the fit of structures containing edges, because undulations of spline surfaces are formed in those places. The deviations resulting from undulations should be as small as possible, however, it should be borne in mind that a continuous curvature spline function cannot accurately describe edges between surfaces. For each of the models, the values of the maximum deviations were not less than $40 \mathrm{~mm}$, for the Geomagic mechanical and 


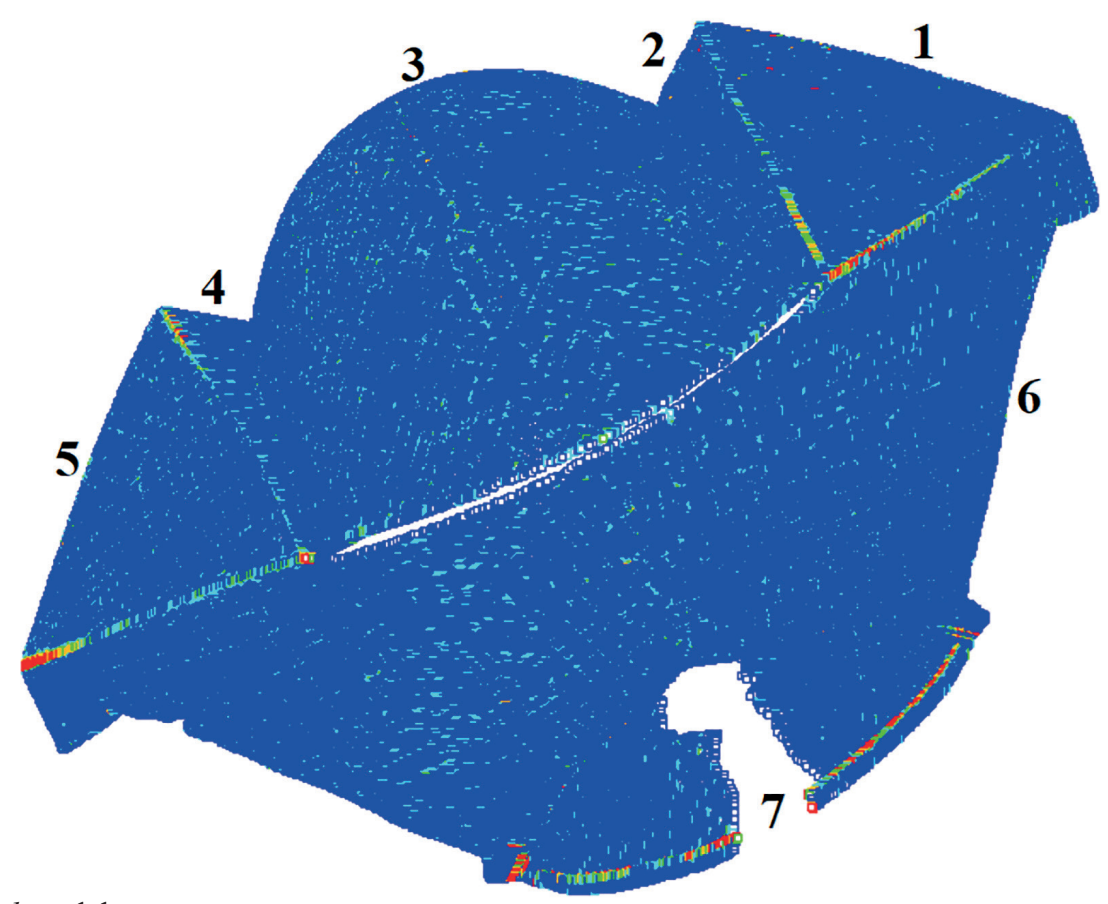

Geomagic mechanical model

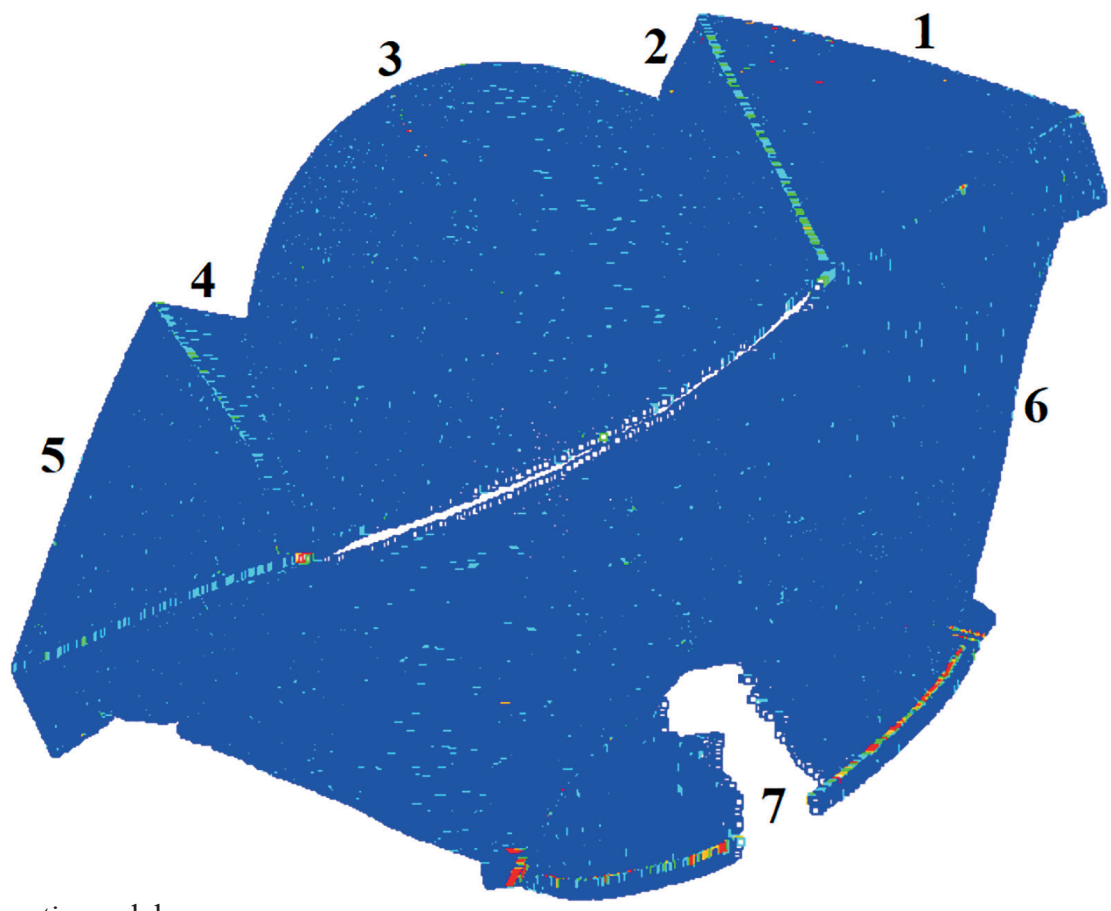

Deviations [mm]

Geomagic semi-automatic model

$(0,5]$

$(5,10]$

$(10,15]$

$(15,20]$

$(20,100]$

Fig. 6. Graphs with point deviations from the surface for models determined in Geomagic Design X: mechanical and semi-automatic

Rys. 6. Wykresy odchyłek punktów od powierzchni dla modeli wyznaczonych w programie Geomagic Design X: mechanicznego i pótautomatycznego 
Solidworks automatic model
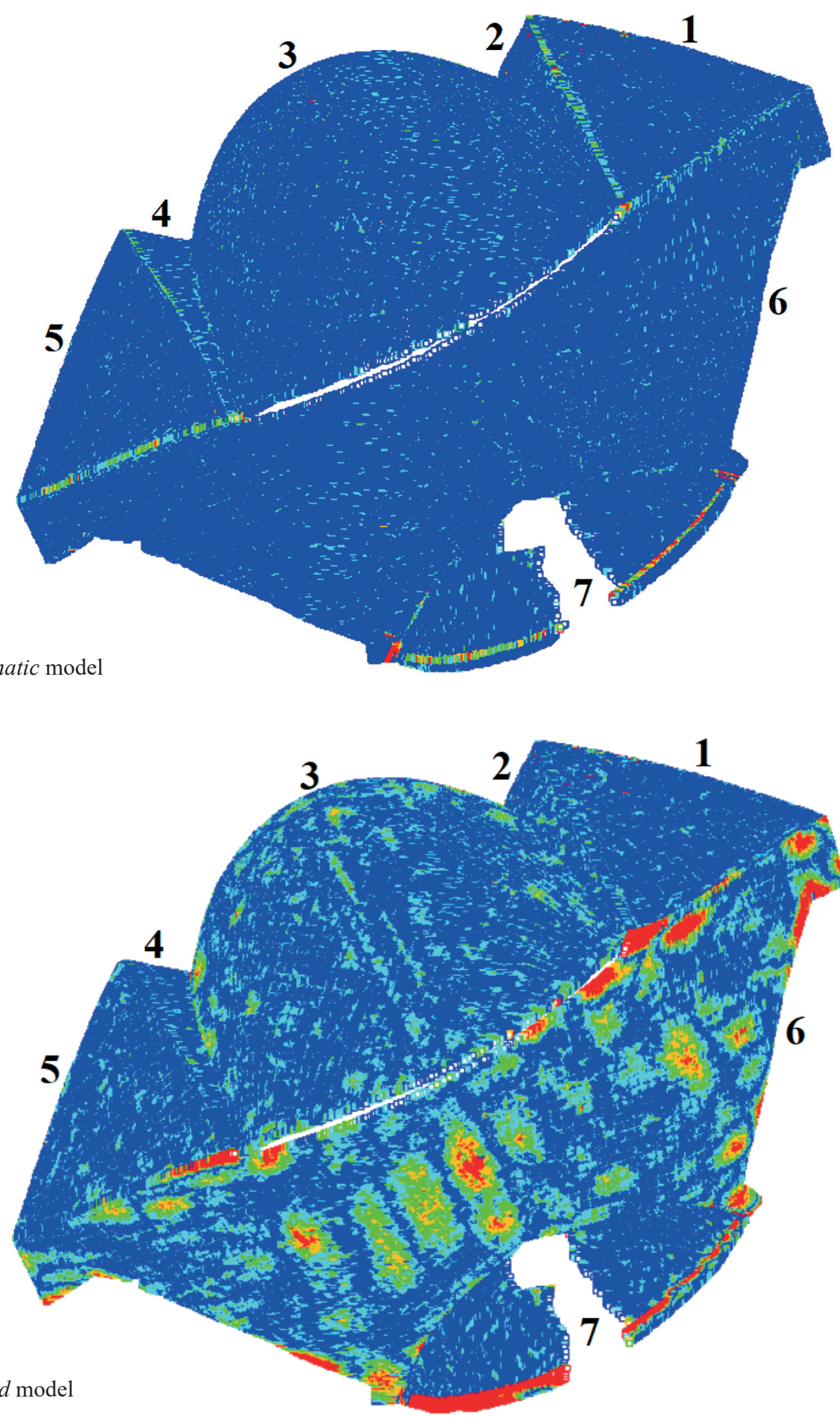

Deviations $[\mathrm{mm}]$

$(0,5]$

$(5,10]$

$(10,15]$

$(15,20]$

$(20,100]$

Solidworks guided model

Fig. 7. Graphs with point deviations from the surface for models determined in Solidworks: automatic and guided

Rys. 7. Wykresy odchyłek punktów od powierzchni dla modeli wyznaczonych w programie Solidworks: automatycznego i kierowanego 

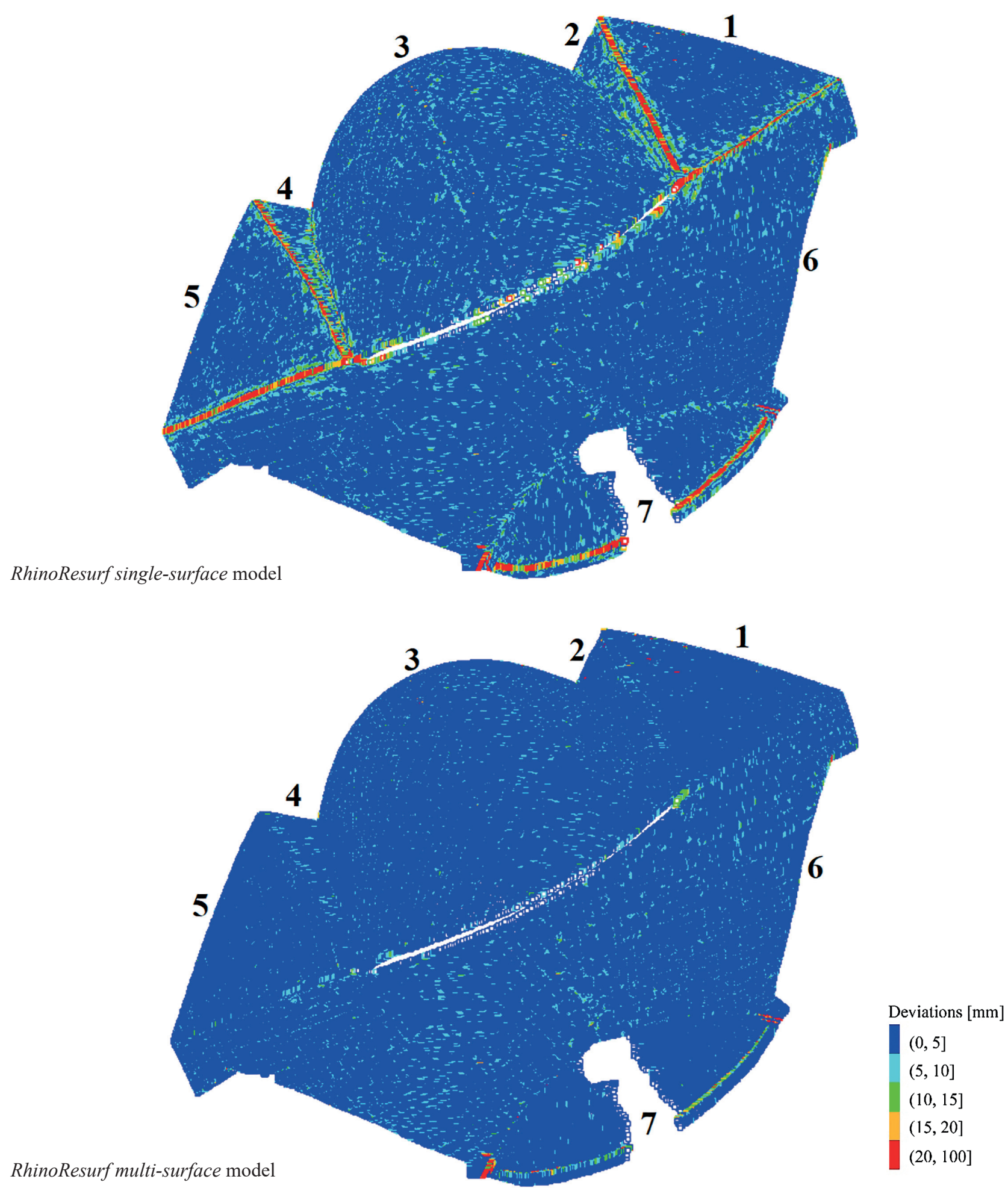

Fig. 8. Graphs with point deviations from the surface for models determined in RhinoResurf software: single-surface and multi-surface

Rys. 8. Wykresy odchyłek punktów od powierzchni dla modeli wyznaczonych w programie RhinoResurf: jednopowierzchniowego i wielopowierzchniowego 
Table 1. Deviations for individual models expressed in percentage

Tabela 1. Udziały procentowe odchyłek dla poszczególnych modeli

\begin{tabular}{|c|c|c|c|c|c|}
\hline \multirow{2}{*}{ Model } & \multicolumn{5}{|c|}{ Deviations in ranges [\%] } \\
\hline & {$[0,5] \quad \mathrm{mm}$} & $(5,10] \mathrm{mm}$ & $(10,15] \mathrm{mm}$ & $(15,20] \mathrm{mm}$ & $(20,100] \mathrm{mm}$ \\
\hline Geomagic mechanical & 96.5 & 2.9 & 0.3 & 0.2 & 0.1 \\
\hline Geomagic semi-automatic & 98.4 & 1.2 & 0.2 & 0.1 & 0.1 \\
\hline Solidworks automatic & 95.9 & 3.5 & 0.4 & 0.1 & 0.1 \\
\hline Solidworks guided & 67.9 & 21.6 & 6.2 & 2.4 & 1.9 \\
\hline RhinoResurf single-surface & 86.2 & 10.7 & 1.8 & 0.6 & 0.6 \\
\hline RhinoResurf multi-surface & 96.8 & 2.8 & 0.2 & 0.1 & 0.1 \\
\hline
\end{tabular}

Table 2. Modelling efficiency parameters: fitting deviations, number of control points and time needed to create the model Tabela 2. Parametry efektywności modelowania: odchyłki wpasowania, liczba punktów kontrolnych oraz czas pracy potrzebny do utworzenia modelu

\begin{tabular}{|l|c|c|c|c|}
\hline \multicolumn{1}{|c|}{ Model } & $\begin{array}{c}\text { Mean deviation } \\
{[\mathbf{m m}]}\end{array}$ & $\begin{array}{c}\text { Maximum } \\
\text { deviation [mm] }\end{array}$ & $\begin{array}{c}\text { Number } \\
\text { of control points }\end{array}$ & Working time \\
\hline Geomagic mechanical & 1.6 & 66.7 & 784000 & $20 \mathrm{~min}$ \\
\hline Geomagic semi-automatic & 1.2 & 49.7 & 528645 & $1 \mathrm{~h}$ \\
\hline Solidworks automatic & 1.7 & 47.3 & 210233 & $1 \mathrm{~h} 45 \mathrm{~min}$ \\
\hline Solidworks guided & 4.8 & 103.7 & 210046 & $50 \mathrm{~min}$ \\
\hline RhinoResurf single-surface & 2.8 & 60.5 & 13098 & $30 \mathrm{~min}$ \\
\hline RhinoResurf multi-surface & 1.6 & 44.3 & 168571 & $2 \mathrm{~h}$ \\
\hline
\end{tabular}

RhinoResurf single-surface models, they exceeded 60 $\mathrm{mm}$, and for the Solidworks guided model, they were as much as $100 \mathrm{~mm}$.

More detailed information about the accuracy is provided by the analysis of the percentage of deviations with specific values (Tab. 1). For the most accurate model, Geomagic semi-automatic, about $98 \%$ of the deviations were less than $5 \mathrm{~mm}$. For models with mean deviations of $1.6-1.7 \mathrm{~mm}$, approximately $96 \%$ of the deviations were below $5 \mathrm{~mm}$. The models with mean deviations of 2.8 and $4.8 \mathrm{~mm}$ had 86 and $68 \%$ of deviations from the smallest value range, respectively. Taking into account the above-mentioned local unevenness of the surface structure (Fig. 4), related to deformations and detachments of the plates estimated at approximately $10 \mathrm{~mm}$, in order to assess the modelling accuracy, it would be advisable to analyse deviations in the range of $0-10 \mathrm{~mm}$. In this case, the most accurate models were obtained by the Geomagic semi-automatic and RhinoResurf multi-surface methods (99.6\% devia- tions). The Geomagic mechanical and Solidworks automatic methods gave a slightly less accurate fit (99.4\% deviations). For the RhinoResurf single-surface model, deviations less than $10 \mathrm{~mm}$ accounted for $96.9 \%$, and for Solidworks guided model only $89.5 \%$.

The best assessment of the accuracy of fitting models is provided by the analysis of the graphs of deviations of points from the surface. According to the previous observations, most of the deviations for all models fall within $[0.5] \mathrm{mm}$. Small deviations with values in the range $(5,10] \mathrm{mm}$ are scattered randomly over the entire surface, which correspond to the aforementioned local surface irregularities. Larger deviations are grouped along the edges. Only the Solidworks guided model shows large deviations in multiple locations on some surface patches, which will be discussed later.

For each of the models, a curved strip of large deviations is visible, extending near the lower edge of the patch 7. These are surface undulations formed along the flange crowning the patch 7 (Fig. 4), which has a double 
fold. The smallest deviations, mostly up to approximately $20 \mathrm{~mm}$, are visible for the RhinoResurf multi-surface model. Both Geomagic models and the Solidworks automatic model have numerous clusters of deviations exceeding $20 \mathrm{~mm}$. The remaining models, with the highest mean deviations, show deviations mostly exceeding $20 \mathrm{~mm}$, and for the Solidworks guided model, they are not only near the edge, but they occupy almost the entire left part of the flange. For all surfaces, at the boundary between the patches 6 and 7, near the ends of the flange, short, transverse strips of deviations with values exceeding $20 \mathrm{~mm}$ are noticeable. They were created as a result of surface undulations caused by narrow, longitudinal strips illustrated in Figure 4. Such elements cannot be well modelled by spline functions, therefore the accompanying significant undulations occurred in all models.

The above-average deviations appeared on a different scale along the edges of adjacent patches for each model. In the Geomagic mechanical model, they reached values exceeding $20 \mathrm{~mm}$ for the lower parts of the patch 5 and the upper part of the patch 1, although the mechanical model should theoretically prevent such situations. A significant improvement was brought by the use of a semi-automatic model, which allowed for manual grouping of regions with a similar structure, which was achieved by leading the boundaries along the edges of the patches. The deviations decreased to about $10-15 \mathrm{~mm}$ for the edges between the patches 1 and 2, and for the remaining patches they did not exceed $10 \mathrm{~mm}$. The deviations along the edges of the Solidworks automatic model had similar values, but they were grouped into more distinct lines, especially for the edge between the patches 5 and 6. Large variations were marked most distinctly along the edges of the RhinoResurf single-surface model. They had values exceeding $20 \mathrm{~mm}$ over their entire length and were accompanied by adjacent deviation strips of slightly smaller values. This was due to the low accuracy of mapping the characteristic details of the structure with a single loft surface. Both the direction of creating spline curves, the loft surface spread over them and the selection of parametrisation could not be optimal, because the edges diverge in different directions. The complete disappearance of these deviations along the edges occurred for the RhinoResurf multi-surface model. This was due to the previous separation of the point cloud along the edges and the construction of separate patches that intersected along the edges, ensuring only the continuity of the function, not its curvature. This resulted in no undulations at the edges. A similar situation occurred for the Solidworks guided model and resulted from the same reason - the guided model was created from separate surfaces corresponding to the structure's patches, which in the final model only retained the continuity of the function. In this model, there are deviations along the edges of the patches 1 and 6 as well as 5 and 6 , but they are due to a different reasons. The guided model was created using a maximum of 20 guided segments for each loft patch in the direction of creating curves and surfaces. The manual does not state what the guided segments are, but they are not the basic segments of the loft surface, which can be concluded from a much larger number of control points than the number of guided segments. Nevertheless, the number of guided segments has an influence on the accuracy of modelling more extensive surfaces. It can be seen that the smallest patches, i.e. 1, 2, 4, 5 and 7, except for the flange, do not contain significant deviations. The patch 3 with a larger area is already in many places covered with numerous groups of deviations of above-average values. The largest, patch 6 , both at the edges and in the centre is covered with numerous groups of large deviations.

Based on the performed analyses, the Geomagic semi-automatic model can be considered the most accurate, although due to better modelling of the patch edges with a slightly larger mean deviation, the RhinoResurf multi-surface model can be indicated as equivalent. A slightly worse fit, mainly due to the edges of the patches, was achieved for the Geomagic mechanical and Solidworks automatic models. Overall, each of these four methods resulted in similar accuracy results. The RhinoResurf single-surface model had noticeably larger edge fitting errors, while the Solidworks guided model was largely created incorrectly.

In addition to the modelling accuracy, an important factor is the complexity of the model, expressed in the number of control points. This complexity did not go hand in hand with the accuracy of the models created. The most accurate Geomagic semi-automatic model uses approximately 530,000 control points, while the comparable RhinoResurf multi-surface model only needs approximately 170,000. The less accurate Geomagic mechanical model contains as much as 780,000 points, and the comparable Solidworks automatic model only approximately 210,000 . The Solidworks guided model, with the same number of points as the automatic 
model, had a much lower fitting accuracy. The RhinoResurf single-surface model, with a lower accuracy than most models, was built using only 13,000 control points.

Model development time was the last factor analysed. It took into account the computation time and the user's working time. The shortest one was for the Geomagic mechanical model (20 min.), in which the calculations were mostly automatic. In order to obtain better accuracy in edge modelling, it was necessary to group regions manually, which was achieved using the Geomagic semi-automatic model. This extended working time to one hour. The Solidworks automatic model required similar manual operations, but due to the long calculation time, the total working time increased to $1 \mathrm{~h} 45 \mathrm{~min}$. Half of that time was needed to create the imprecise Solidworks guided model. The RhinoResurf single-surface model was developed within 30 minutes, while the RhinoResurf multi-surface model was developed the longest $(2 \mathrm{~h})$. This was related to the manual separation of the point cloud along the edges and separate modelling of each of the seven patches.

\section{SUMMARY}

The conducted research allowed to identify a group of methods to correctly model a complex shell structure. The best accuracy results were achieved for the Geomagic semi-automatic model, whose mean deviation of fit was $1.2 \mathrm{~mm}$. It consisted of approximately 530,000 control points and the model construction time was 1 hour. The RhinoResurf multi-surface model had a mean deviation of $1.6 \mathrm{~mm}$, but a better fit at the edges was achieved. This model had three times fewer control points, but it took twice as long to build it. A comparison of these two models offers an interesting view of the modelling tools that use spline surfaces. Geomagic software is the most comprehensive package, and the semi-automatic model allows to precisely model the entire surface in one process with manual support. RhinoResurf belongs to a much less efficient group of software and it did not work well to create an accurate model in one computation process. However, by manually dividing the point cloud into patches along the edges, it was possible to obtain a mean deviation slightly worse than the Geomagic semi-automatic model, with better edge modelling. Manual work was more time-consuming, but had an advantage of the model being less complex. This shows how important in the modelling process is the user's intuition, who can recognise and separate areas of a different shape and create an independent loft surface for each of them. More advanced software, such as Geomagic and Solidworks, relieves the user from manual and time-consuming processes, but it has to find the optimal division into loft areas on its own. This results in a dense grid of fine surfaces that does not correctly represent the structure of the object at all areas. The shape of the loft surface grids created manually and automatically can be compared in Figure 9.

Correct surfaces, although with worse edge approximation, were also created in Geomagic mechanical model and Solidworks automatic model. However, these models differed several times in the number of control points and the construction time. Geomagic mechanical model was created almost six times faster, but it was composed of about four times more control points than the Solidworks automatic model. The RhinoResurf
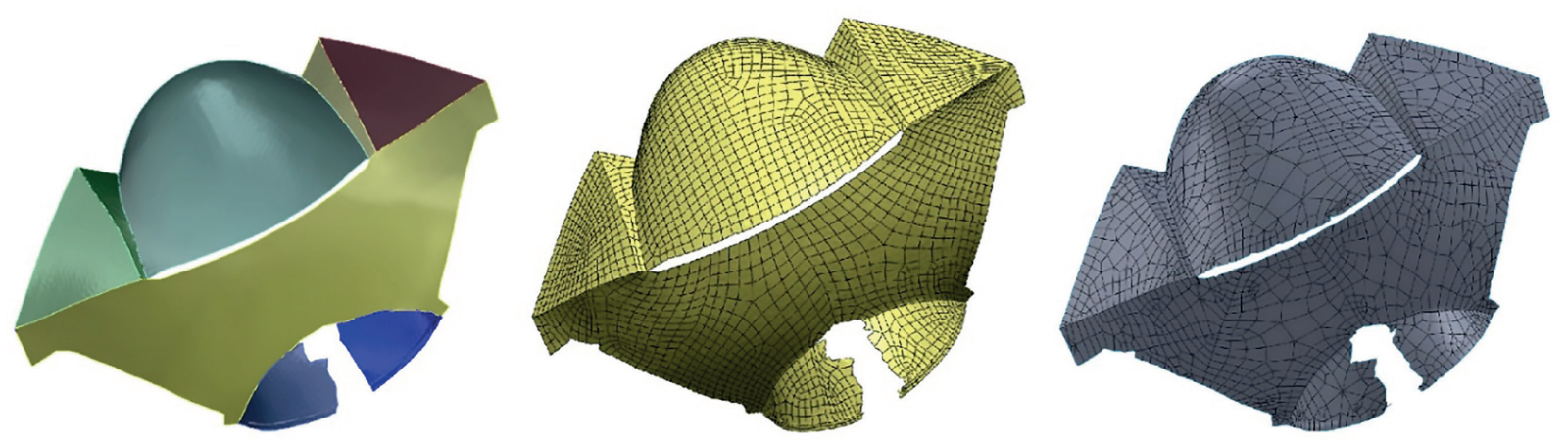

Fig. 9. Loft surfaces for models: a) RhinoResurf multi-surface - determined manually, b) Geomagic semi-automatic - determined automatically, c) Solidworks automatic - determined automatically

Rys. 9. Powierzchnie loft dla modeli: a) RhinoResurf wielopowierzchniowy - określane ręcznie, b) Geomagic półautomatyczny - określane automatycznie, c) Solidworks automatyczny - określane automatycznie 
single-surface model offered significantly worse edge approximation, although its other parameters, i.e. construction time and the number of control points, gave it an advantage over the other models. It can be used in demonstrative modelling, fast and not very complex, but with lower accuracy. The Solidworks guided model modelled large patches of surface incorrectly, with other parameters at an average level and therefore it cannot be considered useful.

The comparison of the results demonstrates how big the differences in modelling are when using different software and tools. Spline surfaces can fit into a data set in many ways. From a technical point of view, the most important evaluation criterion is the accuracy of fitting the surface to the point cloud. From the point of view of model development and storage, the complexity and time of model creation will also be important. It can be assumed that the result with the highest accuracy of fitting is best, but if the accuracy is sufficient for the purpose, other factors will determine the choice of the surface creation method. In four out of six cases, high, similar modeling accuracy was achieved, with large differences in working time and model complexity. In some cases, the time and complexity have the highest priority, not accuracy. Therefore, efficiency depends on the aim of the modeling. The compromise between the analysed factors determines the purpose of the final models, whether they are high-accuracy models, e.g. for deformation analyses, or demonstrative models illustrating the general shape and arrangement of structures.

\section{ACKNOWLEDGEMENTS}

This work was supported by the research subvention of AGH University of Science and Technology No. 16.16.150.545 in 2020.

\section{REFERENCES}

Ahn S.J., "Least squares orthogonal distance fitting of curves and surfaces in space," Springer-Verlag, Berlin, 2004.

Anderson C.W. and Crawford-Hines S., "Fast Generation of NURBS Surfaces from Polygonal Mesh Models of Human Anatomy," State University Computer Science Technical Report CS-99-101, Colorado, Feb. 2000.

Audin M., "Geometry," Springer, Berlin, 2003.

Bhatla A., "Parametrization in curves and surfaces," Term paper, MEC 572 Geometric Modeling in CAD/CAM, Mechanical Engineering Department, SUNY - Stony Brook, 2003.
Brujic D., Ainsworth I. and Ristic M., "Fast and accurate NURBS fitting for reverse engineering," The International Journal of Advanced Manufacturing Technology, 2011, vol. 54, pp. 691-700. DOI:10.1007/s00170-010-2947-1

Eck M. and Hoppe H., "Automatic reconstruction of B-spline surfaces of arbitrary topological type," Proceedings of the 23rd annual conference on Computer graphics and interactive techniques, Aug. 1996, pp. 325-334. DOI:10.1145/ 237170.237271

El-Midany T., Elkhateeb M. and et al., "NURBS Surface Approximation Using Rational B-spline Neural Networks," JCET, Jul. 2011, vol. 1, no. 1, pp. 34-38.

Farin G., "Curves and surfaces for computer aided geometric design," Academic Morgan Kaufmann Publishers, San Francisco, 2002.

Kiciak P., "Podstawy modelowania krzywych i powierzchni: zastosowania w grafice komputerowej: wydanie III," Wydawnictwa Naukowo-Techniczne, 2019.

Koch K.R., "Three-dimensional NURBS surface estimated by lofting method," Springer-Verlag, London, 2009.

Krishnamurthy V. and Levoy M., "Fitting smooth surfaces to dense polygon meshes," Proceedings of the 23rd annual conference on Computer graphics and interactive techniques, ACM SIGGRAPH, Aug. 1996, pp. 313-324. DOI:10.1145/ 237170.237270

Leal Narvaez N.E., Leal Narvaez E.A. and Branch J.W., “Automatic construction of NURBS surfaces from unorganized points," Dyna, 2011, vol. 78, n. 166, pp. 133-141.

Lim C. G., "Universal parametrization in constructing smoothly-connected B-spline surfaces," Computer Aided Geometric Design, 2002, vol. 19(6), pp. 465-478. DOI:10.1016/S01678396(02)00132-2

Piegl L. and Tiller W., "The NURBS book," Springer Science \& Business Media, Berlin, 2012.

Shamsuddin S. M. and Ahmed M. A., "A hybrid parameterization method for NURBS," Proceedings International Conference On Computer Graphics, Imaging And Visualization, International Conference on Computer Graphics Imaging and Visualization, Penang, Malaysia, 2004, pp. 15-20. DOI:10.1109/ CGIV.2004.1323954

Teutsch C., Berndt D., Trostmann E. and Weber M., "Efficient Reconstruction of NURBS surfaces for shape analysis and surface inspection," Fraunhofer Institute for Factory Operation and Automation IFF, Magdeburg, Germany, 2005.

Wang W., Zhang Y., Scott M.A. and Hughes T.J., "Converting an unstructured quadrilateral mesh to a standard T-spline surface," Computational Mechanics, 2011, vol. 48, pp. 477-498. DOI:10.1007/s00466-011-0598-1

Zhang L., Zhou R., Zhu J. and Wu X., "Piecewise B-spline surfaces fitting to arbitrary triangle meshes,", CIRP Annals, Jun. 2002, vol. 51, pp. 131-134. DOI:10.1016/S00078506(07)61483-8

Zhang S., Li Z., Zhang H. and Yong J., "Multi-resolution mesh fitting by b-spline surfaces for reverse engineering," 2011 12th International Conference on Computer-Aided Design and Computer Graphics, IEEE, Jinan, China, 2011, pp. 251-257. DOI:10.1109/CAD/Graphics.2011.65 